\title{
ПРОБЛЕМЫ ЗАКОННОСТИ И СПРАВЕДЛИВОСТИ КАК ПРОБЛЕМЫ БУКВЫ И ДУХА ЗАКОНА
}

\author{
Дорошков В. В.
}

Аннотация: Понятие законности является цуентральным звеном не только в контексте теоретикоправовой разработки проблем построения правового государства, демократизации правовой жизни, оптимизации правотворчества и правоприменения, но и как средство повышения эффективности реализации права, обеспечения юридической ответственности, защчтыь прав и свобод человека и гражданина. В настоящей статье подробно анализируются понятия «законность», «справедливость», «равенство», их значение и взаимоотношение. В этой связи анализируются такие правовые институты, как институт применения сторон и институт частного обвинения. При подготовке статьи были использованы методы: сравнительно-исторического анализа (для изучения динамики исторического развития и реализации принцииов законности и справедливости в различных правовых актах); сопоставительного анализа (для сопоставления доктринальных позиций и содержания принципов в различных отраслях права). Выявлены конкретные примеры несоответствия законов критериям справедливости. Подобные обстоятельства должны выявляться учеными и устраняться законодателями, чтобы практические работники (дознаватели, следователи, прокуроры, судьи) единообразно и справедливо применяли закон. Рассмотренная в статье проблематика будет способствовать выявлению слабых мест в отечественном уголовном прочессе и поможет реформированию судопроизводства в России путем существенных корректив в государственную политику во всех ее областях: законодательстве, правоприменении и развитии правосознания.

Ключевые слова: Законность, Справедливость, Равенство, Принцип, Буква закона, Дух закона, Примирение сторон, Частное обвинение, Реформирование, Несоответствия.

В современной правовой науке не утихают споры по поводу сущности и содержания справедливости и законности, их оснований, критериев, ценностного смысла. Законность и справедливость анализируются не только в контексте теоретико-правовой разработки проблем построения правового государства, демократизации правовой жизни, оптимизации правотворчества и правоприменения, но и как средство повышения эффективности реализации права, обеспечения юридической ответственности, защиты прав и свобод человека и гражданина.

Термин «законность» как принцип уголовного процесса нашел свое отражение в действу- ющем УПК РФ (статья 7). Во-первых, участники уголовного процесса со стороны государства не вправе применять федеральный закон, противоречащий УПК РФ. Во-вторых, суд, установив несоответствие федерального закона или иного нормативного правового акта УПК РФ, принимает решение в соответствии с последним. В-третьих, нарушение норм УПК РФ участниками процесса со стороны государства в ходе уголовного судопроизводства влечет признание доказательств, полученных таким путем, недопустимыми. В-четвертых, определения и постановления этих участников должны быть законными, обоснованными и мотивированными. 
Термин «справедливость» прямо упоминается в части 2 статьи 6 УПК РФ, когда речь идет о наказании. Кроме того, попытка определения справедливости в современном уголовном процессе предпринята в части 2 статьи 389-18 УПК РФ, где через ее антипод «несправедливый приговор», который по виду и размеру назначенного наказания не соответствует тяжести преступления, личности осужденного как вследствие чрезмерной мягкости, так и вследствие чрезмерной суровости.

Чтобы не говорили современные исследователи советского права, но наше поколение юристов воспитывалось на тезисе: «Законно - значит справедливо». Если считаешь, что справедливо будет сделать так, а не иначе - открываешь закон и убеждаешься, что именно так там и написано. Грань между законностью (буквой закона) и справедливостью (духом закона) была очень тонкая.

На реализацию права, на его объективную оценку влияет много факторов. Отклонения от правовых моделей, от нравственных начал человеческого общества порождаются не только юридическими ошибками, но и низким качеством правовых актов, слабой работой государственных органов, невысокой правовой культурой граждан. Особенно в кризисные периоды развития страны принимаются экстренные экономические, политические и правовые меры, не всегда адекватно учитывающие моральную составляющую большинства населения. В результате перед правоприменителями, особенно судьями при назначении виновному меры наказания, остро встает вопрос о соотношении буквы и духа закона. Мне, как ученому, более 30 лет проработавшему судьей, в последние годы довольно часто приходилось сталкиваться с проблемой соотношения законности и справедливости, применять закон в соответствии со своим внутренним убеждением, руководствуясь при этом не только законом, но и совестью, как это регламентировано статьей 17 УПК РФ.

Следует согласиться с мнением Г.В. Мальцева о том, что «правовые нормы, признаваемые в качестве справедливых, не могут и не должны отрицать какие-либо нравственные ценности, становиться на пути осуществления моральных идеалов, противодействовать общественным силам, стремящимся к духовному совершенствованию».

\footnotetext{
${ }^{1}$ Г.В. Мальцев «Нравственные основания права». М., 2008. C. 109.
}

Общеизвестно, что в своем функционировании законность и справедливость воздействуют как на правовую реальность (право, правотворчество, правореализацию), так и на ее идеальное отражение (правосознание). Несмотря на общность объектов функционального воздействия, его предметы, содержание, механизмы для рассматриваемых принципов не являются совпадающими.

С одной стороны, в период строительства правового государства юридизация общественной жизни обусловливает постоянное повышение значимости законности, усиление уделяемого ее обеспечению внимания. С другой стороны, по принципу обратной связи одной из важнейших проблем современности становится обеспечение справедливости права, правовых отношений, правотворческой и правоприменительной практики. В этих условиях важно определить, насколько в действительности принципы справедливости и законности в своем функционировании не совпадают и (или) не согласуются между собой, и если такое несовпадение (несогласованность) присутствует, насколько критичным оно становится в условиях их постепенной активизации.

Понятие справедливости деятельности судебной власти в современную эпоху в большей степени определяется не только нормами внутреннего законодательства, которое органично связано с государственным устройством, обусловленным национальными традициями и т.п., но и нормами и принципами международного права. Международное право вынуждено оперировать в основном оценочными понятиями, что предопределено объективными причинами - различием правовых традиций, понятий, языковыми барьерами и трудностью перевода, отсутствием аналогов отдельных понятий и т.д.

Правовое равенство в условиях состязательности уголовного процесса является предвестником справедливости, логически предполагает преодоление исходного фактического неравенства людей путем создания равенства стартовых возможностей в использовании людьми своих прав и свобод. В правовой науке различают два аспекта справедливости. Во-первых, это справедливость уравнивающая, то есть формальное равенство всех перед законом и судом. Во-вторых, это справедливость распределяющая, пропорциональная («воздаяние равным за равное», «каждому свое», «каждому — по делам его», «каждому воздастся такой мерой, какой он отмеривает другим»). Эти виды справедливости 
взаимосвязаны инее могут существовать друг без друга. Состязательность в уголовном процессе без реального равенства сторон, а лишь равноправия сторон перед судом, без равноправия перед законом, органами предварительного расследования, порой напоминает спор «волка с овцой», которые к тому же по-разному понимают сущность термина «свобода». Перед законом они все должны быть равны, а не равноправны.

В статье 14 ранее действовавшего УПК РСФСР упоминалось об осуществлении правосудия на началах равенства граждан перед законом и судом независимо от происхождения, социального и имущественного положения, расовой и национальной принадлежности, пола, образования, языка, отношения к религии, рода и характера занятий, места жительства и других обстоятельств. В статье 15 УПК РФ говорится лишь о формальном равноправии перед судом стороны обвинения и защиты, то есть об их процессуальном равноправии, Тем самым подчеркивается допустимость состязательности при разном имущественном положении сторон, каждая из которых в силу своего положения вправе привлечь на свою сторону наиболее успешных и грамотных адвокатов или отказаться от их услуг. Подобная ситуация свидетельствует об «узком горизонте» буржуазного права, когда на вопрос неимущего «я имею право?» говорится «да», а на вопрос «я могу?» звучит ответ «нет». То есть, потерпевший имеет право на участие юридически грамотного представителя, но в силу своего материального положения не может его нанять и оплатить услуги. В связи с этим Министерством Юстиции РФ готовятся проекты законов об обеспечении бесплатными юридическими услугами не только обвиняемых, но и потерпевших.

Для того чтобы воздать равным за равное, необходимо поставить стороны в равное положение. И, наоборот, для того чтобы поставить лиц в равное положение, необходимо равное воздаяние, адекватное поведению. Это то, что в политико-юридической мысли называют термином «общество равных возможностей». Если общество (в лице государства) не способно правовыми средствами обеспечивать соответствующее преодоление, то искажается действительный смысл и распределяющей, и уравнивающей справедливости, исчезают механизмы эффективной защиты интересов людей, исчезает возможность обеспечения выживания и развития соответствующего общества.
Если великую российскую мечту рассмотреть в историческом аспекте, то это - построение общества равных возможностей. Общество, которое представляет собой идеал для всех цивилизаций и стран, имеющих корни в христианстве, основанном на равенстве людей перед Богом и природой человека. В. Д. Зорькин справедливо подметил, что «Христианизация Руси - первый прорыв «общества равных возможностей» в нашу реальность. И неудивительно, что эту христианизацию проводил великий князь Владимир - сын не только монарха, но и рабыни, ставшей женой его отца. Равенство, воплощенное уже в «Русской Правде», которая уравнивала элиты и народ перед лицом правовой справедливости. Тогда на Руси впервые был закреплен принцип равной меры правовой ответственности путем уравнивания мер (еще не размеров, а только видов) наказаний. Сердцевина российской мечты - это «общество равных возможностей». А значит, для её достижения наше право должно стать адекватным инструментом реализации правового равенства в обеих его ипостасях - уравнивающей и распределяющей». ${ }^{1}$

Сейчас граждане России все больше хотят равенства -конституционного, правового, реального, в том числе и в уголовном судопроизводстве. Иначе деформируется формально-юридическое равенство и принцип верховенства права, возникнет разрыв между законом и правом, исказится правовой характер власти и ее можно признать несправедливой со всеми вытекающими из этого последствиями. Государство должно играть совершенно особую, консолидирующую, цементирующую роль защитника всего населения страны. Это обусловлено огромными размерами территории России, сложным политико-географическим и экономико-географическим положением, полиэтничным, поликонфессиональным составом её населения и т. п.

Еще один пример несоответствия буквы и духа закона в уголовном судопроизводстве введение института примирения сторон и прекращения уголовных дел не только частного обвинения, но и там, где присутствует публичный интерес. Если обратиться к ст. 76 УК РФ и ст. 25 УПК РФ, то можно убедиться в допустимости в рамках уголовного судопроизводства прекращения конфликта сторон, а соответственно и производства по уголовному делу за примирением

\footnotetext{
' В. Д. Зорькин «Россия будущая - и вечная». Доклад на I международном юридическом форуме (Санкт-Петербург. 20 мая 2011 г.)
} 
сторон. Данный правовой институт в правоприменительной практике постоянно расширяется, совершенствуется. Ему даже посвящено специальное постановление Пленума Верховного Суда РФ № 19 от 27 июня 2013 года.

Что касается дел частного обвинения, то производство по таким делам подлежит прекращению за примирением сторон без соответствующих условий (совершение преступления впервые, заглаживание причиненного потерпевшему вреда). Закон допускает прекращение уголовного дела за примирением сторон за преступление, предусмотренное ст. 128-1 УК РФ (клевета). По смыслу действующего закона допускается прекращение производства по уголовному делу за примирением сторон в отношении лица, которое распространило заведомо ложные сведения, порочащие честь и достоинство другого лица.

В то же время если эти сведения, унижающие честь и достоинство лица распространялись в неприличной форме, даже не заведомо (оскорбление), то данное деяние после декриминализации Федеральным законом от 7 декабря 2011 года теперь не является настолько общественно опасным и преследуется в административном порядке. Однако КоАП РФ до сих пор не предусмотрел института прекращения административного производства за примирением сторон. Следовательно, буква закона не позволяет прекратить производство по делу за примирением сторон в случае, когда в ходе судебного разбирательства не будет установлено заведомой ложности распространенных в неприличной форме сведений, порочащих честь и достоинство потерпевшего.
Согласно же духу закона, если допускается прекращение уголовных дел за примирением сторон, то аналогичный правовой институт должен применяться и при совершении административного правонарушения. Вот наглядный пример тому, как законность не соответствует справедливости.

Следует также учитывать, что КоАП РФ не предусматривает административной ответственности за покушение на административное правонарушение или за приготовление к нему. Положение о том, что состав административного правонарушения составляет только оконченное противоправное деяние, совершенное физическим или юридическим лицом, достаточно четко подчеркнуто в постановлении Пленума Верховного Суда РФ от 24 марта 2005 г. № 5 «О некоторых вопросах, возникающих у судов при применении Кодекса об административных правонарушениях» (пункт 19).

К сожалению, подобных примеров несоответствия законов критериям справедливости еще не мало. Все они должны выявляться учеными и устраняться законодателями, чтобы практические работники (дознаватели, следователи, прокуроры, судьи) единообразно и справедливо применяли закон. Полагаю, что сегодняшняя научно-практическая конференция будет способствовать выявлению слабых мест в отечественном уголовном процессе и поможет реформированию судопроизводства в России путем существенных корректив в государственную политику во всех ее областях: законодательстве, правоприменении и развитии правосознания.

\section{Библиография}

1. Г. В. Мальцев «Нравственные основания права». М., 2008.

2. В. Д. Зорькин «Россия будущая - и вечная». Доклад на I международном юридическом форуме (Санкт-Петербург. 20 мая 2011 г.)

\section{References (transliterated)}

1. G. V. Mal'tsev «Nravstvennye osnovaniya prava». M., 2008.

2. V. D. Zor'kin «Rossiya budushchaya - i vechnaya». Doklad na I mezhdunarodnom yuridicheskom forume (Sankt-Peterburg. 20 maya 2011 g.) 